\title{
Speciation and quantification of sulfur distributed in the Ediacaran limestones: Implications for diagenetic mobilization of sulfur species
}

\author{
FUMIHIRO MATSU'URA ${ }^{1}$, RYOICHI NAKADA ${ }^{2}$, \\ YUSUKE SAWAKI ${ }^{3}$, YUICHIRO UENO ${ }^{4}$, MASAFUMI \\ SAITOH $^{5}$, IORI KAJITANI ${ }^{1}$ AND TOMOHIRO USUI ${ }^{6}$ \\ ${ }^{1}$ JAXA \\ JAMSTEC \\ ${ }^{3}$ The University of Tokyo \\ ${ }^{4}$ Tokyo Institute of Technology \\ ${ }^{5} \mathrm{UNIL}$ \\ ${ }^{6}$ Institute of Space and Astronautical Science, JAXA \\ Presenting Author: matsuura.f@elsi.jp
}

The sulfur isotopic composition of sedimentary pyrite has been known to express microbial activities which involve large sulfur isotope fractionation; however, in addition to the microbial processes, environmental factors such as sedimentation rate, redox condition, and iron availability have come to be known to have strong impacts on the isotopic composition and concentration of sedimentary pyrite. Sulfur isotopic composition of sedimentary pyrite in the terminal Ediacaran strata is known to be high as $+40 \%$ globally. Both global process-low oceanic sulfate or increasing pyrite burial — and local process - closed system or hydrothermal effect - were suggested to account for the high $\delta^{34} \mathrm{~S}_{\text {pyrite }}$. The limestones in the terminal Ediacaran Shibantan Member, Dengying Fm have much lower amount of pyrite $-10 \mathrm{~s}$ to $100 \mathrm{~s}$ of ppm - compared to the limestones and dolostones in the preceding Ediacaran Doushantuo Fm-1000s of ppm-, which indicate the preservation process of sulfide expelled from sulfate reducing microbes in Dengying limestones are different from that of the Doushantuo limestones. Here we carried out $\mu$-XRF and S K-edge XANES analyses of limestones of the Ediacaran Doushantuo and Dengying Fms using a drilling core samples collected from Three Gorges area, south China. The results show maximum $1237 \pm 315 \mathrm{ppm}$ of abundant organic sulfur species such as thiophenes and thiols were exclusively existing in the Dengying limestones, which indicate organic matter outcompeted iron to scavenge the sulfide in sediments. Thus, we suggest iron limitation induced the high $\delta^{34} \mathrm{~S}_{\text {pyrite }}$ values in the Dengying limestones. Besides, we quantified the impact of diagenesis on carbonate associated sulfate (CAS) by comparing CAS content in micrite and sparite. High strontium content $(>1 \%)$ and existence of celestine $\left(\mathrm{SrSO}_{4}\right)$ in sparite indicate the Dengying limestones used in this study were only suffered from marine diagenesis. Our results show the CAS content decreased from $277 \pm 288 \mathrm{ppm}$ in micrite to $229 \pm 138 \mathrm{ppm}$ in sparite, which suggests CAS concentration decreased even during marine diagenesis in which porewater sulfate was $\mathrm{mM}$ level. Thus, we conclude the isotope and concentration of CAS in micrite are the most appropriate to extract the information of paleo-oceanic sulfate. 